\title{
IFIGÊNIA: DE PROSTITUTA À HEROÍNA
}

Josefa Rouse ${ }^{1}$

\section{RESUMO}

Este trabalho analisa a representação da mulher negra a partir das obras Sortilégio - Mistério Negro (1951) e Sortilégio II - Mistério Negro de Zumbi Redivivo (1976/77), dramaturgia escrita e reescrita por Abdias do Nascimento no bojo do Teatro Experimental do Negro. Nos debruçamos em especial às questões relativas às personagens femininas (Ifigênia, as Ialorixás e o coro de mulheres). Perpassamos questões do feminismo negro e suas interseccionalidades, a religiosidade transposta para o discurso teatral, a afetividade da mulher negra e o lugar de fala destas mulheres no teatro nacional com o intuito de pensar suas implicações no teatro moderno e contemporâneo e observar como a cena pode colaborar para lançar outro olhar sobre suas imagens, a partir das mudanças de uma obra a outra, como no percurso da personagem Ifigênia, mais contundente - ainda que dentro de um estereótipo controverso. A pesquisa desdobrou-se a partir de revisão bibliográfica, com a finalidade de apontar para certas modalidades de representação da mulher negra que se apresentam como estereótipos dominantes, a fim de repensar processos de desumanização vividos em especial por mulheres negras, e apontar caminhos emancipatórios que possam revelar suas subjetividades por meio da cena.

Palavras-chave: dramaturgia; feminismo negro; mulheres negras; teatro negro.

\section{IFIGÊNIA: FROM PROSTITUTE TO HEROIN}

\begin{abstract}
This work aims to analyze the representation of the black woman from the works Sortilégio I Black Mystery (1951) and Sortilégio II - Black Mystery by Zumbi Redivivo (1976/77), written and rewritten by Abdias do Nascimento in the bulge of the Experimental Theater of Black. We will focus in particular on issues concerning female characters (Iphigenia, the Yalorixás and the women's choir). It permeates issues of black feminism and its intersectionalities, the religiosity transposed to theatrical discourse, the affection of the black woman and the place of speech of these women in the

1 Josefa Rouse é atriz no grupo AIVU Teatro; Mestra em Artes Cênicas pelo Instituto de Artes da UNESP Universidade Estadual Júlio de Mesquita Filho, tendo defendido em 2019 a dissertação: Mais e mais perto de nós: Imagens e personificações da mulher negra no teatro brasileiro dos anos 1940 a 2008, no contexto da experiência cênica e do ativismo das mulheres negras segundo Sortilégio I, Sortilégio III e Sete Ventos; licenciou-se em 2011 em Artes Cênicas pela mesma universidade; e cursa o último semestre de Bacharelado em Filosofia, na UNIFESP Universidade Federal do Estado de São Paulo.
\end{abstract}


national theater. In order to think about its implications in the modern and contemporary theater and to observe how the scene can collaborate to cast another look on its images, from the changes from one work to another, as in the path of the more forceful ifigenia character - even inside. of a controversial stereotype. The research unfolded from a literature review, aiming to point to certain modalities of representation of black women that present themselves as dominant stereotypes, in order to rethink processes of dehumanization lived especially by black women, and point out emancipatory ways that can reveal their subjectivities through the scene.

Keywords: black feminism; black women; black theater; dramaturgy

Sortilégio - Mistério Negro $(1951)^{2}$ foi apresentada em primeiro lugar no Rio de Janeiro, em 21 de agosto de 1957, dirigida por Léo Jusi, com cenografia de Enrico Bianco, tendo no elenco Heloísa Hertã, Stela Delphino, Matilde Gomes, Ítalo Oliveira, Abdias do Nascimento, Léa Garcia, Helba Nogueira, Amôa, Ana Peluci, Edi Santos, Marlene Barbosa, Conceição do Nascimento e o coral da Orquestra Afro-Brasileira, regido pelo maestro Abigail Moura. Depois, houve uma apresentação única na capital paulista, em 20 de outubro de 1957. Ressaltamos que a obra sofreu censura neste período, e sobre a sua liberação Almeida (2017) comenta que ela se deu em um estado e depois em outro, pois os órgãos de censura eram estaduais (o que explica a diferença entre as duas datas de apresentação), até que foram todos reunidos num só órgão federal, em 1968, ainda mais centralizador e autoritário, com o recrudescimento do regime militar (CRUZ; GOMES, 2007).

Sortilégio - Mistério Negro é um drama ritual que narra o percurso realizado por Emanuel em busca de redenção e da sua identidade de homem negro, que até então recusara. Neste percurso, as memórias do que viveu o acompanham. Ifigênia é uma de suas principais recordações, pois se sente culpado por tê-la abandonado, casando-se com uma mulher branca que, por fim, negou-lhe a possibilidade de ser pai, abortando um filho que julgava ser dele. Margarida é a esposa que não queria ter um filho negro, apesar de ter se casado com um homem negro.

Para um melhor entendimento anexamos uma sinopse desta primeira versão: Emanuel, um homem negro, advogado, casa-se com uma mulher branca numa tentativa de embranquecimento. Mas Margarida, a esposa branca, aborta um filho seu, para não ter um filho negro. Emanuel a mata

2 Este artigo foi escrito a partir da dissertação de mestrado defendida em junho de 2019 no IA-UNESP que tem como título Mais e mais perto de nós: Imagens e personificações da mulher negra no teatro brasileiro dos anos 1940 a 2008, no contexto da experiência cênica e do ativismo das mulheres negras segundo Sortilégio I, Sortilégio II e Sete Ventos, tendo sido orientada pela Prof ${ }^{a}$. Dra. Lúcia Regina Vieira Romano. 
foge. Na fuga, é guiado por Exu e Pombagira - a segunda, representada pela personagem Ifigênia ${ }^{3}$, uma mulher negra e sua ex-namorada. Seguem até um terreiro, onde se encontram com sacerdotisas da religião afro, que juntamente com Ifigênia acompanham Emanuel, no percurso, relembrando sua trajetória de vida e todas as formas com que recusou sua identidade negra, entre elas, a negação da religião; a rejeição a si própria - seus modos de vestir e comportar-se-; o esquecimento do samba e de sua origem na favela, etc. Emanuel, consciente de sua identidade de homem negro, reconcilia-se consigo mesmo e termina por aceitar a religião e o sacrifício a ele impingido, num rito de passagem que simboliza seu reencontro com sua negritude e ancestralidade.

O drama ritual estrutura-se no sentido de que as entidades que povoam a fábula movem o destino das personagens, com o objetivo de transformar suas relações sociais, não apenas no nível individual, mas coletivo. Sobre esta escolha, Eliza Larkin Nascimento (2003, p. 327) destaca:

\begin{abstract}
Soyinka $^{4}$ identifica a origem do drama ritual africano no momento em que o espaço cósmico - "lar natural das deidades invisíveis, local de descanso para os que partiram e pousada de transição para os não-nascidos” - solicita do ser humano a necessidade de "desafiar, confrontar e ao menos iniciar uma afinidade com o reino do infinito". No drama ritual, a arena da confrontação protagonizada pelo herói para esse fim em benefício da comunidade é o palco.
\end{abstract}

A obra mobiliza-se pela presença de Exu, entidade responsável pela comunicação entre os humanos e as divindades, entre o aiyê e o orum - a terra e o céu, outra característica que pode ser destacada dentro da definição de drama ritual. Martins (1995) acrescenta que o termo "ritual” refere-se à cosmogonia africana, permitindo que relacionemos o texto de Nascimento ao patrimônio cultural afro: "Drama e ritual confundem-se na África, pois o contexto do drama ritual é uma totalidade cósmica, um espaço sígnico global que envolve os seres humanos e os deuses” (MARTINS, 1995, p. 96-7).

O mistério negro, do título da obra, evoca o culto às divindades ancestrais, remetendo

3 Na primeira versão da obra Sortilégio - Mistério Negro o nome da personagem Ifigênia é grafada com “E”, e na segunda com "I", vamos adotar a escrita com "I" em todo o trabalho.

4 Wole Soyinka é um dramaturgo pós-colonial nigeriano. Sobre ele, Figueiredo menciona: “O ritual faz parte intrínseca da consciência revolucionária e da visão dramática do autor aqui estudado, servindo, ainda, como enquadramento principal para uma técnica teatral que incorpora, simultaneamente, elementos tradicionais africanos e estratégicas artísticas da literatura e do teatro ocidentais” (FIGUEIREDO, 2008, on-line). 
também aos Mistérios do teatro medieval. Assim, remonta a uma dupla referência, em universos distintos e complementares, “[...] a mítica, firmada pelas divindades e mistérios dos ritos afrobrasileiros, e a estética, vinculada ao gênero teatral da Idade Média e ao teatro ritual africano” (MARTINS, 1995, p. 104). O drama constitui também um rito de passagem, que permite a reinscrição de Emanuel no universo da cultura negra, após o jogo de máscaras no qual a personagem embranquece metaforicamente, para sobreviver num mundo de referências brancas, omo um mecanismo de defesa. Ainda segundo Martins (1995), a peça pode ser considerada um drama interior, em que a personagem reconstitui sua experiência individual e coletiva, num movimento que o leva ritualmente à encruzilhada que simboliza a sua própria existência, entre valores ocidentais e africanos.

\section{A dimensão religiosa}

Podemos observar, analisando a obra como um todo e seu contexto, diversos aspectos que inserem Sortilégio - Mistério Negro, no que se convencionou chamar de Teatro Negro. O dramaturgo é um homem negro, comprometido com as questões dos negros; os temas tratados dizem respeito à vida dos negros, tanto nas referências à religiosidade afro-brasileira e à sua ética os pontos dos orixás, a musicalidade, os tambores, a presença dos orixás, as oferendas a eles dedicadas, a fé ritualizada, expressa nas palavras da tradição, de origem iorubá; a submissão às divindades -, quanto nos temas de cunho político-social, entre eles, a crítica à chamada democracia racial brasileira; a violência policial; a grita frente à falta de oportunidades de mudança social; a tentativa de desconstrução dos estereótipos; e a ação individual enquanto uma tomada de consciência dos valores da comunidade, resvalando na coletividade.

A dimensão religiosa é um dos traços primordiais da obra. Podemos avaliar a importância que o autor confere ao uso do ritual do candomblé para a identidade e sobrevivência do negro, mesmo após a escravidão, a partir do excerto abaixo:

O candomblé nasce, então, como campo possível de resistência e sobrevivência cultural e étnica do negro escravizado, e como a possibilidade de manutenção de uma identidade e solidariedade que o processo de escravidão, libertação e marginalização do negro não logrou destruir. (CARNEIRO e CURY, In: NASCIMENTO (Org.), 2008, p. 102).

Para nos aproximarmos desta reflexão, abordaremos antes algumas significações dos orixás para, em seguida, enfatizarmos sua importância na obra estudada, observando como permeiam todos os eventos da trama e como se relacionam com as demais personagens. Segundo Santos 
(2002, p. 76), as entidades do candomblé são:

São massas de movimentos lentos, serenos, de idade imemorial. Estão dotados de um grande equilíbrio necessário para manter a relação econômica entre o que nasce e o que morre, entre o que é dado e o que deve ser devolvido. Por isso mesmo estão associados à justiça e ao equilíbrio. São as entidades mais afastadas dos seres humanos e as mais perigosas. Incorrer no desagrado ou na irritação de um òrìsà-funfun é fatal.

As Filhas de Santo comentam na primeira cena sobre o fato de Emanuel renegar a Exu, o que o desagrada e o irrita, e é isso o que deflagra e justifica a personagem realizar esta jornada ritual até o terreiro de candomblé que é conduzida, principalmente, pelo próprio Orixá:

II Filha de Santo - Preto quando renega a Exu...

I Filha de Santo - ... esquece os orixás...

II Filha de Santo - ... desonra a Obatalá...

III Filha de Santo (vigorosa) - Merece morrer. Desaparecer.

I Filha de Santo (lenta) - Palavras duras. Nossa missão não é de rancor.

III Filha de Santo (sádica, perversa) - Exu tremia de ódio, espumava de raiva, quando ordenou: "Eu quero ele aqui, de rastros, antes da hora grande".

I Filha de Santo (contemporizando) - Tremia. Não de ódio. Exu só tem amor no coração. Exu só faz o bem.

III Filha de Santo - E o mal. Faz também o mal. A cólera de Exu vai desabar sobre a cabeça dele. Aqui, quando...

II Filha de Santo - ... soar doze badaladas, Exu sai para a rua. (NASCIMENTO, 1961, p. 164-65).

O plano supranatural, portanto, é o motor do "segredo" que faz as trajetórias das personagens acontecerem. Aos poucos, esse mistério será apresentado e concretizado, por meio dos elementos que fazem parte da cultura, da filosofia e da religião yorubá. A peça vai sendo permeada pelos cantos dos pontos de diversos orixás, Obatalá/Oxalá (na mitologia yorubá, o criador do mundo, dos homens, animais e plantas), Inhansã ${ }^{5}$ (a rainha dos ventos e das tempestades), Iemanjá (a rainha do mar), Xangô (orixá da justiça, dos raios, dos trovões e do fogo), Oxunmaré (representa a fortuna, abundância, prosperidade e riqueza), Ogun ${ }^{6}$ (orixá do ferro e da guerra), Exú (em yorubá, significa esfera; é o Orixá da comunicação, do movimento). São estes cantos, assim como os toques dos tambores, atabaques e agogôs que conferem o tom ritualístico à obra, fazendo com que a presença dos Orixás se manifeste. A sonoridade é chave para tornar esse plano palpável, ainda que não haja a presença corpórea das deidades.

5 Alguns termos durante o texto podem estar grafados na língua original, Yorubá. De modo que optamos por escrever o próprio termo Iorubá com Yorubá, como no original.

6 Ogun na língua Yorubá é assim grafado, e em português se grafada com “m”, vamos utilizar a grafia em Iorubá, sendo fiéis à grafia nas duas versões, a não ser nas citações de outros autores. 
Sobre este caráter simbólico das representações litúrgicas, Sodré (2010, p. 329) nos aponta o conceito de Arkhé:

[...] aquilo que se subtrai às tentativas puramente racionais de apreensão, enquanto algo de fundamental de que não se recorda, que falta, mas que se simboliza no culto aos princípios cosmológicos (os orixás, as divindades) e aos ancestrais que presentificam os princípios inaugurais.

Com respeito à tradição negra na formação social brasileira, Sodré (2010) conclui que “A reinterpretação afro-brasileira dessa memória sempre foi, ao mesmo tempo, ético-religiosa e política” (SODRÉ, 2010, p. 329). A afirmação vai em direção das intenções do dramaturgo de fazer viva a tradição da religião afro-brasileira como forma de resistência, relacionando as vivências cotidianas dos negros ao ritual religioso, por meio das representações dos orixás, dos cantos, dos toques dos tambores e das figuras das Filhas de Santo e da Yalorixá. Assim como as palavras de origem Yorubá que emergem aqui e ali, esses elementos simbolizam o sistema de crenças da cultura africana, materializando a força mágica do candomblé e transportando as personagens para o reencontro com suas ancestralidades. Esse encontro não se dá no passado, mas pela ativação, no tempo presente, da memória atemporal:

III Filha de Santo (continua sem ouvir) - De arrepiar os cabelos. Exu vai parar, vai confundir o tempo: passado e presente, o que foi e o que estiver acontecendo (NASCIMENTO, 1961, p. 165).

No excerto da obra citado acima, em relação a esse tempo que Exu confunde, podemos aludir que são essas memórias, esses instantes do passado que se mesclam ao presente, trazendo à tona os momentos vividos antes do assassinato de Margarida (a esposa branca) que, ao mesmo tempo levam Emanuel a se religar com sua ancestralidade. Portanto, Emanuel revisita estes acontecimentos a partir deste estratagema de Exu, num espaço-tempo mítico, condensado, e não mais de ordem causal, linear:

O mundo do candomblé abre as portas para um outro tempo. Em contraposição à linearidade e fragmentação do tempo cronológico, o mítico é um "tempo conquistado em sua totalidade, um ciclo inteiramente acabado e realizado" (Verant, 1973, p.87)”. Poderíamos dizer que o processo de "entrar" no tempo mítico é, para este indivíduo, um processo de auto(re)conhecimento, no qual ele vai descobrir sua realidade primordial e compreender-se como ser integral, parte do todo. (CARNEIRO e CURY, In: NASCIMENTO (Org.), 2008, p. 99).

De acordo com Juliana Elbein dos Santos, uma das funções de Exu, além de ser o mensageiro dos Orixás para os homens, é a abertura de caminhos para a manifestação do mistério:

[...] consiste em solucionar, resolver todos os "trabalhos", encontrar os caminhos apropriados, abri-los ou fechá-los e, principalmente, fornecer sua ajuda a fim de mobilizar e desenvolver tanto a existência de cada indivíduo como as tarefas específicas atribuídas e delegadas a cada uma das entidades sobrenaturais (SANTOS, J., 2002, p. 132). 
Na primeira versão da obra se destaca a participação de Exu na jornada empreendida por Emanuel na sua busca por reencontrar-se enquanto homem negro, na primeira versão, a lança que sacrifica Emanuel é a de Exu, como se destaca na fala da Filha de Santo III, a seguir:

“FILHA III - feliz - Ninguém toca nele. Só a lança de Exu!” (NASCIMENTO, 1961, p. 165).

A julgar por sua importância dentro do candomblé, é Exu a entidade que permeia as duas obras; em dado momento, surge sua voz em busca de Emanuel, o que confirma que na cosmogonia da peça, é Exu o responsável por fazer com que o protagonista masculino cumpra seu destino e chegue ao local do seu sacrifício, passando pela encruzilhada até atingir o terreiro. Entretanto, será por meio de Ifigênia, a Pombagira, que Emanuel seguirá o percurso que o levará ao terreiro para cumprir o seu sacrifício ritual.

Conforme Santos (2002, p. 163) discute, Exu é o cobrador de todos os sacrifícios:

Èsù, é o princípio reparador do sistema Nàgô. É o controlador rígido de todos os sacrifícios. Inspetor geral, segundo Idowu (1962); "oficial de polícia imparcial”, segundo Abimbola (1969:393) que diz: "a ação de Èsù é a de [...] punir os contraventores, particularmente aqueles que negligenciaram fazer o sacrifício prescrito".

A ligação entre Emanuel e Ifigênia dá-se também pela mística, como veremos a seguir. A personagem, na rubrica inicial da primeira versão do texto, é identificada como “negra, prostituta”; o que liga sua cor negra à atividade da prostituição. Nessa perspectiva, a personagem estaria de acordo com a imagem dominante na literatura, na música e nas mídias de comunicação de massa (em especial, as novelas) que atrela a mulher negra e a "mulata” à imagem de fogosa e fácil, com um corpo objetificado e sempre disponível para o sexo. Todavia, Ifigênia procura ao longo da peça seu lugar verdadeiro, distanciando-se do seu “valor de uso".

A alusão ao nome de Santa Ifigênia pode corresponder à postura crítica do autor, que demarca a negação da religião afro-brasileira da personagem Ifigênia em seu nome de batismo. A personagem, desse modo, “cita” a história da Santa Ifigênia, uma mulher negra (da região da Etiópia) que rejeitou a religião de seu povo para adotar e propagar o cristianismo. No caso da personagem da obra, ao rejeitar a religião de seu povo, Ifigênia abre caminho para seu “castigo” (e futura religação com a tradição): a Pombagira teria se apossado de seu corpo, o que a leva ao reencontro com a religiosidade afro-brasileira e com sua ancestralidade. Ao final da segunda versão, inclusive, Ifigênia ascende ao plano mítico, tornando-se uma mulher guerreira reverenciada no terreiro, com destino diverso da Santa cristã. 
Nascimento (1980), em referência às culturas Banto e Yorubá sobre os nomes Exu ${ }^{7}$ e Pombagira, aponta que os dois termos são equivalentes. De modo semelhante, Maria Elise Rivas, no artigo Nem Maria, nem Eva, apenas pombagira!, cita os autores que equivalem a palavra pombagira à bobomgira ou bobomjirá, termo que designa Exu em Angola (de tradição banto) e que em iorubá equivale a Exu. Ainda em banto, a palavra "gira” significa rumo ou caminho. Rivas (2015) ressalta também que a palavra “pomba”, no nordeste do país, designa o órgão genital masculino, enquanto que no sul do Brasil dá nome ao órgão genital feminino, como decorrência em solo brasileiro a Pombagira pode ser identificada como Exu feminino.

Assim, parece-nos evidente uma relação complementar e de inseparabilidade entre Exu e Pombagira, conforme o trecho abaixo:

Ésù [...] é o portador mítico do sêmen e do útero ancestral e como princípio de vida individualizada ele sintetiza os dois. É por isso que, frequentemente, ele é representado sob a forma de um par, uma figura masculina e uma figura feminina unidos por fileiras de cauris (SANTOS, J., 2002, p. 163).

A Pombagira, acrescenta Rivas (2015), atua em diversos campos, não só sobre questões amorosas, sexuais ou de conflitos de violência doméstica. Sua interferência manifesta-se em questões financeiras, doenças variadas, desentendimentos e também na relação com os mortos. No Brasil, entretanto, a Pombagira ficou atrelada à imagem da prostituta, à mulher de moral corrompida, de tal modo que está muito ligada às questões das mulheres. Rivas (2015, p. 86) complementa:

Mas, se observamos da ótica dos valores africanizados, teremos uma mulher de poder, que conhece os segredos da criação, da vida e da morte, bem como o campo dos desejos, mulheres que são capazes de fazer os homens respeitarem o seu poder, chegando a travestirem-se de mulheres e dançarem como elas num ato de reconhecimento e temor.

Expõe que "Na umbanda, costuma-se afirmar que as encruzilhadas em forma de ' $\mathrm{X}$ ' (com quatro pontas) são destinadas a Exu e as em ' $\mathrm{T}$ ' (com três pontas), à Pombagira”. Podemos entender, portanto, que essas duas forças que atravessam a obra - Ifigênia, tomada pela Pombagira, que é ao mesmo tempo Exu - são acompanhantes de Emanuel até o cumprimento de seu sacrifício. A importância de Ifigênia, assim, ganha destaque, mesmo na primeira versão do texto (quando, conforme já discutido, seu destino permanece inconcluso). Enquanto Exu faz a conexão entre os

7 Na obra, essa potência é referenciada por duas das três qualidades de Exu, que são os nomes pelos quais pode ser chamado: Exu tranca ruas, Pelintra (o boêmio, amante da noite e da rua) e Barabô (que serve a Xangô e Imemanjá). 
humanos e os orixás, cobrando Emanuel pelos sacrifícios e fazendo com que ele atinja seu destino,

Ifigênia também abre e fecha os caminhos do ex-namorado.

\section{Constituição das subjetividades: resistência ou recusa?}

Emanuel, personagem principal da obra, em detrimento de sua subjetividade singular, absorve as subjetividades hegemônicas, na tentativa de moldar-se a uma forma em que não se encaixa. Recusar sua cor, sua cultura e sua religião são atitudes que, no trabalho da psicanalista Souza (1993), coadunam-se com os relatos de seus entrevistados, em trecho de sua introdução:

Passaram por nossos olhos, ouvidos e pele, fragmentos dos discursos colhidos das histórias de vida dos nossos entrevistados, onde ouvimos falar do negro enquanto sujeito que introjeta, assimila e reproduz, como sendo seu, o discurso do branco. O discurso e os interesses (SOUZA, 1993, p. 32).

A primeira alusão feita à Ifigênia, tanto na primeira como na segunda versão do texto, aparece por meio das falas das Filhas de Santo:

II FILHA DE SANTO (conciliadora) - Há uma preta também na história: Ifigênia. III FILHA DE SANTO (polêmica) - Tinha horror de ser negra.

II FILHA DE SANTO - Mas botaram nela o nome de santa: Ifigênia. Uma santa trigueira. III FILHA DE SANTO (veemente) - Negra. Santa negra. Ninguém escapa da sua cor. I FILHA DE SANTO (lírica) - Queria ser branca... branca por dentro... ao menos por dentro...

III FILHA DE SANTO (violenta) - Ninguém escolhe a cor que tem. Cor da pele não é camisa que se troca quando quer. (exaltada) Raça é fado... é destino!

II FILHA DE SANTO (ingênua) - Será que por isto foi castigada? Pombagira entrou no corpo dela e não saiu mais [...] (NASCIMENTO, 1961, p. 164).

No trecho, conhecemos que a moça também rejeitou sua cor e origem. Na primeira versão, contudo, se Emanuel reconcilia-se com sua identidade e ancestralidade, pouco sabemos do que ocorre com Ifigênia, que não tem um desfecho mais elaborado.

Podemos observar, nos excertos abaixo, o desprezo às raízes africanas demonstrado pelas duas personagens; preterimento que favorece as referências eurocêntricas e a subjetividade imposta pelo branco colonizador:

[...] Ifigênia reaparece em traje de ballet clássico, coroa do bailado do cisne na cabeça [...] IFIGÊNIA - lentamente como num sonho - Está a me esperando, querido... O que é que há? Não me acompanha hoje? Acabou a aula de ballet [...]

IFIGÊNIA - Como outra coisa! Não discutimos o assunto tantas vezes? E a conclusão não foi sempre: ballet clássico? Você não me queria misturada aos sambas do morro, de gafieira. Me proibiu de frequentar os "terreiros" onde aprendia a dançar o ritmo dos pontos sagrados [...] (NASCIMENTO, 1961, p. 173 grifos do autor).

Conforme exposto, as duas personagens têm seu processo de subjetivação borrado pelas imposições de uma sociedade que as padroniza e que exige que interiorizem os padrões dominantes, 
deixando de reconhecer seus próprios referenciais e permanecendo, enfim, como um “outro” defectivo. Nos termos de Souza (1993, p. 30): “O negro passou a acreditar no conto, no mito, e passou a ver-se com os olhos e falar a linguagem do dominador”.

Beatriz Nascimento, numa de suas falas narrada no filme Orí (1989) discute as questões do sofrimento e da perda da imagem, aludindo à experiência traumática que os negros escravizados vindos de África compartilham em terras diaspóricas. Podemos entender tal perda da imagem como parte do exílio forçado, do distanciamento das origens e das culturas originárias para a adoção dos referenciais locais. A perda da imagem, entretanto, dificulta a reconstrução dos laços de origem necessários para a construção da subjetividade negra que, por esta razão, fica embaçada. Assim, a subordinação às subjetividades do opressor e sua forma de vida mostra-se como um forte elemento de dominação. Nesse sentindo, Beatriz Nascimento conclui: "É preciso a imagem para recuperar a identidade. Tem-se que tornar-se visível, porque o rosto de um é o reflexo do outro, o corpo de um é o reflexo do outro e em cada um o reflexo de todos os corpos” (ORÍ, 1989).

As personagens Ifigênia e Emanuel sofrem desta perda da imagem, adotando uma falsa identidade quando desprezam seus referenciais - o samba, a religião, os costumes, etc - para a aceitação de outras fronteiras e do destino das subjetividades hegemônicas: “Corpo de repente aprisionado pelo destino dos homens de fora. Corpo/mapa de um país longínquo que busca outras fronteiras, que limitam a conquista de mim” (NASCIMENTO apud RATTS, 2006, p. 68).

O corpo figura como memória, cheio de significados; um corpo que tanto ocupa os espaços quanto se apropria dele. As festas e os encontros de negros não seriam só um encontro de corpos, mas também um reencontro de imagens que podem ser reconhecidas por meio da identificação do movimento corporal dos antepassados; num jeito do corpo entrar em determinados lugares (RATTS, 2006). Local de reconstituição de identidades e subjetividades, o corpo seria um lugar de recriação, também, do pensamento negro.

\section{Violências Físicas e simbólicas}

Frente às violências físicas e simbólicas (xingamentos, agressões e silenciamentos) infringidas às personagens negras em Sortilégio - Mistério Negro, resta certa dúvida se a reprodução na cena das agressões contra as mulheres, tão presentes na vida ordinária, funciona como um protesto, ou mais um reforço do quadro dominante, diante do desfecho dado à personagem ${ }^{8}$. Ao

8 Já na segunda versão, ao contrário, apesar de todas as violências contra Ifigênia repetirem-se, seu final aporta uma 
lado disso, as falas e atitudes de diversas personagens parecem reforçar o estereótipo da mulher negra construído socialmente. Apesar das situações estarem atreladas a certo "passado”, o texto revela valores que expressam um desprezo latente pelas mulheres, conforme podemos observar nas falas destacadas abaixo:

IFIGÊNIA - (irrompe na cena e fala agressiva) - Foi porque quis. Não obriguei. Nem ao menos pedi.

EMANUEL - Você acabou de contar sua vergonhosa história com o tal José Roberto. Bancou a ingênua... a seduzida...

IFIGÊNIA - Banquei, não: fui. Eu também era donzela, ora essa!

IFIGÊNIA - Ah! Meu filho... direito eu tinha. Então um doutor em leis não sabe disto? A lei estava do meu lado. A lei protege as menores de dezoito.

IFIGÊNIA - Dura lex, sed lex. Não é assim que se diz? Eu tinha dezessete anos. Donzela $[\ldots]$

VOZ AGRESSIVA - Acabe logo com esses fricotes vagabunda.

IFIGÊNIA - (tornando-se sincera) - Amargura?... Sim, é verdade. A eterna amargura da cor. Compreendi que a lei não está do lado da virgindade negra [...]

$[\ldots]$

EMANUEL (afastando-se) - [...] Minha vontade era te arrebentar. Antes tivesse feito. Assim nosso amor teria continuado. Para sempre (pausa, calmo) Tolice falar. Águas passadas não movem moinho. Você é uma causa sem remédio. Uma causa? Prostituta negra nem chega a tanto. Pode ser quando muito uma chaga, uma mancha: na pele e na alma. (raiva crescente) Daqui sinto o bafo podre de sua boca profanada. A morrinha azeda que vem de ti me dá náuseas. Agora não precisa mais escolher. Aceita qualquer um. Sem dúvida debaixo dos lençóis todos os corpos são iguais. O desejo não vê cor. Vê a fêmea e o macho. [...]

IFIGÊNIA - Sem importância pra você. Eu, desde o instante em que perdi minha "importância" tive meu caminho traçado: o caminho da perdição. Não houve escolha (NASCIMENTO, 1961, p. 178-80, 188).

Na obra, Ifigênia não só precisa moldar-se a uma subjetividade eurocêntrica, como também aos ditames do mundo masculino. Portanto, apenas segue os passos de Emanuel, concordando com sua forma de ver o mundo, numa tentativa de reaver seu amor. Mas ele a pretere, justamente, por ela ser uma mulher negra. A ausência de autoestima da personagem feminina, entretanto, a impede de exercer sua autonomia e superioridade moral na interação com as personagens masculinas. O ciclo da violência contra a mulher é nutrido também por essa baixa autoestima, que não deixa que se reconheça a agressão como injusta, e não meritória ou corretiva.

EMANUEL - Sabia que vinha, Ifigênia. E não me abandonaria. Nem um minuto deixei de pensar em você. De te pertencer. Juramos nunca nos separarmos, lembra-se? Sempre juntos. Juntos sempre. Enfrentando, desafiando tudo. Sempre te amei. Você sabe disso. Mesmo daquela vez que te bati, foi por te querer demais. Você chamou a todos nós de "negros amaldiçoados”. Passou a detestar a própria cor. A futricar a vida de Margarida. Perdi o

mudança qualitativa. 
controle. Mas juro que bati pensando no teu bem. Queria te fazer sofrer. Para te redimir. Te lavar por dentro e por fora. E você seria outra. Fui um bruto, reconheço. Mas não fiz por ruindade. Pensou que te batia para defender Margarida? Bobinha. Era só por você. Unicamente por você. [...]

$[\ldots]$

(Emanuel esbofeteia Ifigênia. Impassível, Ifigênia caminha até a ribanceira. Acena com o lírio chamando alguém. Ele avança brandindo a lança)

EMANUEL - Ordinária. Prostituta de corpo, prostituta de alma (NASCIMENTO, 1961, p. 190-192; 193).

Os trechos acima trazem à tona um dos resquícios do processo de escravização, remetendo aos estupros reiterados contra as mulheres negras escravizadas. No período da escravidão, a violação tinha serventia variada: servia para realizar o desejo sexual do senhor; iniciar sexualmente os filhos da casa grande; engravidar as negras e usá-las para amamentar os filhos das sinhás; aumentar a produção de crianças para serem escravizadas e suprir o mercado interno com sua venda; empregá-las como escravas de ganho em casas de prostituição, ou simplesmente, para marcar a mulher, submetendo-a ao seu dono.

Davis (2016), ao discorrer sobre os sucessivos estupros e o racismo presente nestes atos, conclui que a imagem do homem negro como estuprador (que gerou dezenas de linchamentos e mortes de, acusados por mulheres brancas - ainda que sem provas) associa-se à da mulher negra como presa do uso sexual de seus corpos:

A imagem fictícia do homem negro como estuprador sempre fortaleceu sua companheira inseparável: a mulher negra como cronicamente promíscua. [...] Se elas são vistas como "mulheres fáceis" e prostitutas, suas queixas de estupro necessariamente carecem de legitimidade (DAVIS, 2016, p. 186).

Ifigênia é vítima desse tipo de desvalor. Quando vai à delegacia acompanhada de Emanuel (que é advogado) para denunciar o estupro é chamada de vagabunda pelo delegado. O comportamento da autoridade reitera o descaso frente às violências sofridas por mulheres negras e nos faz lembrar a ciência médica e seu esforço na inferiorização dos negros (e minimização das violências contra eles perpetradas). O caso é exposto por Correa (1996), sobre as análises do médico e eugenista Nina Rodrigues:

Nada exemplifica mais graficamente este modo de raciocínio do que a classificação das formas de hímen feita por Nina Rodrigues em suas análises médico legais. Embora as mulheres mestiças apresentassem, como as brancas, as normas "mais variadas" de hímen, "as recém-nascidas, negras ou mestiças" apresentavam com frequência uma forma de hímen que facilmente se confundia com o hímen rompido. (Essa classificação parece ter facilitado enormemente seu trabalho como perito nos casos em que meninas negras ou mulatas violadas eram examinadas por ele - e sua queixa desqualificada.) "No que diz respeito às negras, as formas de hímen são mais simplificadas” (CORREA, 1996, p. 44).

Aqui, a medicina, um instrumento da ideologia, atua para justificar a visão já operante socialmente, e não como verificação científica. Sua função, portanto, é de autorizar a violência. 
Assim como em Nina Rodrigues as experiências ginecológicas do médico estadunidense, James Marion Sims (1813-1883) eram abusivas, na medida em que ele assegurava que as mulheres negras tinham maior tolerância à dor, portanto, justificando seu emprego em seus experimentos. Somente depois de verificada a eficácia de determinada cirurgia no corpo das pacientes negras, sem o uso de anestésicos, é que ele as realizava em mulheres brancas, porém, com anestesia!

O poder usurpador sobre o corpo da mulher negra, contemporaneamente, guarda paralelos com a violência doméstica de gênero. Também, está traduzida no corpo objetificado, um corpo dedicado ao trabalho braçal, explorado e exaurido até o limite de suas forças. Esse corpo, alijado de direitos mínimos, ainda reverbera a pergunta de Sojouner Truth, abolicionista afro-americana, escritora e ativista dos direitos da mulher, em seu discurso $E$ eu não sou uma mulher?,de 1851. Sua história é emblemática: num encontro feminista, majoritariamente composto por mulheres brancas de classe social alta, ao lado de homens brancos, ela pede a palavra e manifesta-se, quando se discute sobre o direito das mulheres:

Nunca ninguém me ajuda a subir numa carruagem, a passar por cima da lama ou me cede o melhor lugar! E não sou uma mulher? Olhem para mim! Olhem para o meu braço! Eu capinei, eu plantei, juntei palha nos celeiros e homem nenhum conseguiu me superar! E não sou uma mulher? Eu consegui trabalhar e comer tanto quanto um homem - quando tinha o que comer - e também aguentei as chicotadas! E não sou uma mulher? Pari cinco filhos e a maioria foi vendida como escravos. Quando manifestei minha dor de mãe, ninguém, a não ser Jesus, me ouviu! E não sou uma mulher? (TRUTH, 1851 apud RIBEIRO, 2017, p. 20).

\section{Afeto e preterimento}

As questões de afeto e preterimento na vida cotidiana levantadas pelas interações homemmulher na peça são marcantes para a definição da natureza dessas relações dramáticas. Ou seja, quando na obra Ifigênia é preterida por Emanuel, que escolhe se casar com uma mulher branca, vemos replicados dados sociais referentes aos tipos de união usualmente praticadas por casais unirracias (entre pessoas negras) e inter-raciais. Sobre este tema, principalmente, no caso da união estável do casamento, Souza (2008) aponta dados da cidade de São Paulo em 2008, que indicam que homens negros preferem relacionar-se com mulheres brancas. Os motivos são próximos aos da personagem Emanuel, que visa na união com Margarida a aceitação de classe e a ascensão social. Para Souza (2008, p. 75):

As mulheres entrevistadas e as participantes do grupo focal concordam que os homens negros jovens, em idade de escolher a parceira conjugal, tendem a preferir a mulher branca, em detrimento da mulher negra. Segundo estas mulheres, esta escolha é mais comum entre os homens negros que buscam uma ascensão social ou aqueles que já ocupam uma posição socioeconômica considerada vantajosa. 
Considerando a inversão do par, quando das relações entre homens brancos e mulheres negras, a assimetria tende a ser considerada menos aceitável. A antropóloga e professora Lélia Gonzalez relata a recepção que teve da família do marido, um homem branco, ao saber que a relação do casal não era de concubinato. Ela recorda: “Quando eles descobriram que estávamos legalmente casados, aí veio o pau violento em cima de mim: claro que eu me transformei numa 'prostituta', numa 'negra suja' e coisas desse nível” (GONZALEZ apud RATTS; RIOS, 2010, p. 52).

Seu relato reflete as hipóteses da pesquisa de Souza (2010), que demonstra a dificuldade da mulher negra em manter um relacionamento estável, pois ela é pouco cogitada para o casamento. A ascensão social que a branquitude, pela via da união conjugal, pode conferir ao homem negro, dessa forma, não pode ser conferida à mulher negra.

Quando em Sortilégio-Mistério Negro, Emanuel se vê cercado pela polícia e atormentado pela consciência de ser um homem negro, entendendo o inútil processo de inserção no mundo branco, percebe em Ifigênia sua única salvação. O diálogo, que começa violento, vai sendo atenuado, até que ele oferece a Ifigênia o amor e a atenção que lhe fora antes negado:

EMANUEL - Seduzida você! Botar a mão num marido branco. Isto sim, era o que você queria. Marido branco... ainda que forçado pela polícia.

[...]

IFIGÊNIA (sarcástica) - E você, com quem casou? Com negra por acaso? Negro formado só quer saber de branca. Loura. (NASCIMENTO, 1961, p. 178)

EMANUEL (explicativo, sincero) - Você já observou como os brancos olham pra você? Com ar de donos? Está assentado na consciência deles. Nem se dão ao trabalho de exame. Basta desejar uma negra, e pronto: dorme com ela. $\mathrm{O}$ que altera mais uma negra no bordel? Tinha certeza que você não seria minha. Nem minha nem de qualquer outro rapaz de cor. Uma negra formosa como você! (NASCIMENTO, 1961, p. 173-174)

IFIGÊNIA - Ah, sim? Conversa. Vivia enrabichado pela branca. Uma obsessão. Só falava em branca, branca, branca. Uma vez pequei um caderno de poesia dele. Estava escondido, mas descobri. Sabem o que tinha? Um inacabável "Cântico dos Cânticos à Eva Imaculada". Colo de marfim... pele alva de neve... ancas alabastrinas... cabelos de orvalho amanhecente... Cretino. (NASCIMENTO, 1961, p. 187)

EMANUEL (violento) - Maldita polícia atrás de mim. (pausa breve; Ifigênia sorri) Está rindo. Mas sabe que não matei. Você sabe, não sabe? (emoção crescente) Por que não conta tudo? Diga a polícia que não matei Margarida. Prometo ir embora com você. Não é que você quer? Vamos viver juntos. Nem que seja na casa da rua Conde Lage. Tenho medo, Ifigênia... [...] (NASCIMENTO, 1961, p. 174).

O convite é feito num contexto de fragilidade, de ambas as partes, num “clima” avesso ao romantismo e que mistura acusações, sofrimentos e esperanças. As questões que Sortilégio apresenta, aqui emergentes, são vivências cotidianas de negação de si, que se revelam em tentativas 
desesperadas de adequação a uma forma de estar no mundo que não condiz com a realidade dos homens e mulheres negros. Além disso, são construções da subjetividade que resultam da interiorização de valores que parecem perenes, os quais tão longamente têm sido mantidos. No início da década dos anos 1990, podemos verificar como essas questões pouco haviam mudado, de acordo com os relatos de Souza (1993), baseados em entrevistas com mulheres. No relato de uma delas, verificamos uma aproximação ao que se constitui a relação entre Emanuel e Ifigênia, expresso de forma violenta e explicitamente declarada: “[...] M. foi o único negro que me falou o que realmente sentia - e que era o mesmo que eu sentia. Ele me diz que uma mulher negra de minissaia, uma buceta preta não dá tesão nenhum [...] (Carmem).” (SOUZA, 1993, p. 64).

Este processo compulsório de interiorização de uma lei contrária a eles mesmos foi aquele vivenciado pelas personagens de Emanuel e Ifigênia e que só poderia tê-los levado ao fracasso. A escolha, entretanto, começa a ocorrer depois que tomam consciência da impossibilidade de sucesso, e não antes dessa percepção. Seus destinos, então se recompõem na busca pela identidade e, uma vez cruzados transformam-se. A dupla, por fim, entende-se como negra, dois sujeitos dotados de uma subjetividade negra, impossível de esconder ou escamotear.

Ainda assim, parece haver em Emanuel uma tentativa de culpar Ifigênia, ao dizer que os brancos a olham e a têm quando querem, mas que ele sabia que ela não seria de nenhum homem negro. A constatação, ainda que pareça injusta no aspecto interpessoal, é acertada no enquadramento da problemática social: a entrega voluntária do afeto, no trecho, mistura-se ao entendimento do lugar objetificado destinado à mulher negra. Se levarmos em conta as violências demonstradas anteriormente, a mulher negra no contexto da sociedade brasileira só poderia ser de um homem branco, mesmo que comparada à imagem da prostituta (a profissão em que, de fato atua): se não é possível por amor, é apenas deste modo, como objeto, que a personagem pode estar acompanhada.

\section{Lugares sociais impostos}

Na obra quando Ifigênia é abandonada por Emanuel, bem como, deixa de lado seu sonho de ser artista, para seguir um dos estigmas sociais da mulher negra, enxergando na prostituição o único caminho possível; o que aparece sintetizado a seguir:

IFIGÊNIA - Sem importância pra você. Eu, desde o instante em que perdi minha "importância" tive meu caminho traçado: o caminho da perdição. Não houve escolha (NASCIMENTO, 1961, p. 188).

Ela entende seu destino como inexorável, traçado após ter sido abusada, sem perspectivas de 
apoio. Sua compreensão de si não significa o entendimento das forças sociais que a oprimem, mas apenas da dor a que foi submetida. Assim, não encontra sequer uma rede que a sustente e, sendo ela mesma o sustento de sua família, aceita a condição de prostituição. Como a maioria das mulheres negras, o fato de ser o esteio da família (inclusive para os parceiros) implica na aceitação de condições menos favoráveis a elas. Um exemplo - para citar apenas um - do funcionamento desse mecanismo perverso, que impede a pessoa negra de obter melhores oportunidades e condições sociais, ainda que tenha capacidades múltiplas, cito um trecho de Djamila Ribeiro (2018, p. 15-16):

Depois de passar na faculdade de jornalismo, comecei a procurar emprego. Apesar de falar inglês e ter recebido prêmios escolares, uma "amiga" da minha mãe me ofereceu uma vaga de auxiliar de serviços gerais na empresa de que era gerente para me "ajudar”. Eu limpava e servia café, mesmo tendo currículo melhor do que os das moças que trabalhavam no escritório.

Pode-se observar o quanto é difícil quebrar a estrutura do racismo, que se expande das estruturas das organizações para as interações interpessoais e, consequentemente, para a experiência subjetiva:

Assim, a principal tese de quem afirma o racismo institucional é que os conflitos raciais também são parte das instituições. Assim, a desigualdade racial é uma característica da sociedade não apenas por causa da ação isolada de grupos ou de indivíduos racistas, mas fundamentalmente porque as instituições são hegemonizadas por determinados grupos raciais que utilizam de instrumentos institucionais para impor seus interesses políticos e econômicos (ALMEIDA, 2018, p. 30).

A maioria dos textos teatrais, principalmente, escritos por dramaturgos brancos, reforça os estereótipos das personagens negras, mantendo-as em lugares inferiores, entendendo estes lugares como normatizados. Com relação à Ifigênia em Sortilégio, ao mesmo tempo em que a personagem tem como profissão a prostituição, - o que poderia ser entendido como um reforço da imagem, considerando a falta de desfecho de sua história -, a segunda versão vem questionar este lugar, a partir do momento em que ela também se reencontra com a sua identidade e subjetividade negra, assumindo um papel de destaque na cena final, passando de uma representação negativa para uma positiva.

Outros trechos da obra apresentam alguns pontos que constatam a posição única e determinada a ser aceita pelas mulheres negras, e fazendo uma denúncia da falta de oportunidades dadas a elas e os privilégios dos brancos em relação aos negros que determinam a escassez de opções:

IFIGÊNIA - Satisfazendo meus desejos, - meus caprichos - (mordaz) estou conquistando meu espaço, cavalgando minha lua, como você diz...

EMANUEL (bebendo) - A glória, a fama que ajudei a conquistar! Te embriagaram mais que esta cachaça. O público te aplaude. Os jornais te chamam de "grande artista". E você 
perde a cabeça. Só pensa nos brancos que te podem dar oportunidades...

IFIGÊNIA - Negro é maldição. Estou farta de imundícies. Como frequentar lugares decentes? Que rapaz de cor me ofereceria a festa dessa noite? (sincera) Você compreende, não é, meu bem? Não se zangue. Eles só vão me levar a uma boate. Está bem? (espera resposta que não vem) Você não diz nada? Faz parte da minha carreira, querido... Hum, está cada vez mais piegas. Igualzinho namorado de subúrbio.

EMANUEL - [...] Mas você não se entregou ao José Roberto por amor. Ou desejo. Puro interesse.

IFIGÊNIA - Usei meu corpo como se usa uma chave. Você me sugeriu imitar as colegas brancas. Então? Qual era a vida delas? Você sabia: vestidos elegantes... perfumes franceses... música... uísque... No princípio, oh! Como tudo isso me encantava!

EMANUEL - Também te encantavam os homens. Deitou com um...Depois com todos eles... Esqueceu?

IFIGÊNIA - Esquecer?... Não. Eu não tinha ainda dezessete anos e te amava, gostava de ti como jamais gostei de nenhum outro homem. Mas, precisava vencer. Do meu talento não queriam saber. Só do meu corpo! Fiz dele minha arma. Depois aconteceu o que não previ [...] (NASCIMENTO, 1961, p. 180-181)

$[\ldots]$

IFIGÊNIA - Eu precisava vencer. Os brancos têm o privilégio: sem eles, nada feito. Enquanto Emanuel... amava Margarida [...] (NASCIMENTO, 1961, p. 188).

Nascimento (1961) acrescenta no desenho do campo social a imposição de um lugar social objetificado para a mulher negra também no “mundo do teatro”. A carreira de atriz, portanto, não é apenas a expressão de um sonho, mas também um caminho para o sucesso que se constrói a partir de outra espécie de prostituição, baseada no uso do corpo em troca de vantagens sociais e financeiras. Almeida (2018) comenta sobre a manutenção do racismo, principalmente no que concerne à mulher negra, exercida pelo imaginário por intermédio dos meios de comunicação e da indústria cultural. Esses são os braços da ideologia dominante que, assim como o sistema educacional, definem a mulher negra como se fossem vocacionadas para os trabalhos “corporais”, nos quais se incluem as atividades domésticas e braçais e a sexualização. Esse mesmo sistema, que define as estruturas econômicas, políticas e jurídicas por meio das quais passam atuar, irá manter as mulheres negras, em sua maioria, com os menores salários, fora dos espaços de decisão e expostas aos mais diversos tipos de violência.

Neste sentido, a personagem Ifigênia, com pouco espaço para o exercício de sua autonomia, tem sua individualidade atrelada à identidade do herói, sofrendo junto com ele todas as dificuldades, que são potencializadas em sua experiência pessoal, pois que acumula uma dupla opressão, por ser uma mulher e negra numa sociedade racista e sexista.

Lélia Gonzalez (1984) revela algumas das faces do racismo e sexismo expressas nas construções do imaginário, por meio das representações da mulata, da doméstica e da mãe preta. Segundo a autora, as imagens mais presentes e replicadas é a dupla imagem de mulata e doméstica, sendo o termo “mulata” absolutamente pejorativo, mas no qual se mantém escamoteado pela 
visibilidade sexual dada às mulheres negras em alguns espaços, como por exemplo, no carnaval. Isso permite que “mulata” seja lido por alguns como positivo, quando o termo - que foi criado nos tempos do cativeiro - designa o fruto da relação de um cavalo com um jumento (um animal elevado e outro, de baixo nível), gerando um híbrido infértil, a mula.

No mesmo estudo, a autora aponta os estereótipos continuados nas profissões designadas às mulheres negras, em seus termos, "Mulher negra, naturalmente, é cozinheira, faxineira, servente, trocadora de ônibus ou prostituta.” (GONZALEZ, 1984, p. 226). Discute ainda que o mito da democracia racial exerce sua violência simbólica sobre a mulher negra a partir do endeusamento carnavalesco, que se apaga ao final da festa, quando ela se transfigura na empregada doméstica. Profissão, oportunidade de reconhecimento social e o imaginário, portanto, estão entrelaçadas outro aspecto do racismo estrutural que, segundo Beatriz Nascimento (2006), opera simultaneamente em diferentes níveis:

[...] a ideologia, onde repousa o preconceito, não está dissociada do nível econômico, ou do jurídico-político; não está nem antes nem depois destes dois, também não está em cima ou embaixo. A ideologia em suas formas faz parte integrante e está acumulada numa determinada sociedade, juntamente com outros dois níveis estruturais (NASCIMENTO apud RATTS, 2006, p.101).

Desde modo, podemos observar como tanto na arte como na vida, estes papéis reservados às mulheres negras se repetem e se perpetuam até os dias de hoje, e como é importante derrubar este tipo de representação racista para que possamos ter dramaturgias sem estereótipos e sem objetificação das mulheres, mas que lhes confira humanidade e é, o que nos parece, pretendeu Abdias do Nascimento em sua segunda versão da obra que analisaremos a seguir.

\section{Um outro Sortilégio}

Sortilégio II - Mistério Negro de Zumbi Redivivo mantém a mesma estrutura dramatúrgica da escrita anterior, com algumas alterações que destacaremos a seguir, a partir da análise em comparação. Na versão escrita entre 1976 e 1977, os assuntos também permanecem: a questão do branqueamento, com uma referência direta na dramaturgia (numa fala da mãe da personagem branca, Margarida); as questões de identidade e subjetividade; a violência policial; e a religiosidade fortemente marcada, nas presenças das entidades, nas rubricas dos toques dos tambores, nos pontos cantados para os orixás e nas palavras de origem Yorubá. No aspecto das encarnações da mulher negra, tendo Ifigênia como centro, podemos afirmar que ocorre uma mudança significativa: ela continua designada como prostituta, mas de forma temporal e não definitiva, como veremos mais 
adiante. Equivale a esta guinada de ponto de vista a entrada de outros assuntos, por exemplo, na cena emblemática do Quilombo de Palmares, que trataremos, também, a seguir.

Sortilégio II foi escrita no período em que o autor esteve na Universidade de Ilé, na Nigéria. Algumas das mudanças efetuadas, Custódio (2011) atribui ao contato do dramaturgo com o Panafricanismo durante o seu autoexílio nos EUA, em período anterior, de 1968 a 1981. Segundo o autor, portanto, estas mudanças correspondem a uma consciência acumulada e ampliada no que diz respeito às dimensões política e cultural da diáspora negra9 :

A négritude foi a expressão literária do pan-africanismo. Foi por ela que Nascimento teria adentrado esse universo conceitual, em uma ressignificação política em seu discurso de elementos oriundos da esfera da cultura. Assim, podemos dizer que o pan-africanismo foi importante para a determinação de um novo discurso ideológico de Nascimento durante seu autoexílio (CUSTÓDIO, 2011, p. 90).

Ainda sobre o embasamento conceitual das alterações e sobre as referências teóricas de Abdias Nascimento para esta nova escrita, Custódio (2011) destaca características históricas deste período, que permitiram o fortalecimento de um pensamento sobre a negritude, motivando as mudanças da obra como um todo:

A importância desses elementos na segunda versão faz referência à centralidade de dois
aspectos no discurso ideológico do autor do período: (1) apropriação das manifestações
culturais de origem africana como foco de resistência cultural, e (2) incorporação dessa
apropriação em uma escala transnacional de resistência contra a opressão racial sofrida pelo
negro. Esses dois aspectos podem ser encontrados em diversos trechos da obra, que foram
inseridos nessa segunda versão (CUSTÓDIO, 2011, p. 125).

Porém, as mudanças que vamos destacar dizem respeito, mais especificamente, às personagens femininas, entre elas, a inserção da personagem Yalorixá; o estatuto dado às Filhas de Santo, com a escrita de falas que a elas, agora, são atribuídas; e a mutação da personagem Ifigênia, que nesta segunda versão tem um novo desfecho, de grande importância para a obra como um todo. A nosso ver, nesta versão, o destino de Ifigênia condiz com o seu percurso dramático e com a importância que merece.

9 Segundo Gilroy (2012) em seu prefácio a edição brasileira de seu livro sobre a diáspora negra: [...] parece imperativo impedir que a diáspora se torne apenas um sinônimo de movimento. [...] Sob a ideia-chave da diáspora, nós poderemos então ver não a "raça”, e sim formas geopolíticas e geoculturais de vida que são resultantes da interação entre sistemas comunicativos e contextos que elas não só incorporam, mas também modificam e transcendem (GILROY, 2012, p. 22, 25). 
Para uma melhor compreensão anexamos uma sinopse, também, para esta segunda versão: Emanuel, um homem negro, advogado, casa-se com uma mulher branca numa tentativa de embranquecimento. Mas Margarida, a esposa branca, aborta um filho seu, para não ter um filho negro. Emanuel a mata e foge. Na fuga, é guiado por Exu e Pombagira - esta, representada pela personagem Ifigênia - uma mulher negra e sua ex-namorada. Seguem até um terreiro, onde se encontram com as sacerdotisas da religião afro. O acompanham Ifigênia, a Yaolorixá e as Filhas de Santo e relembram sua trajetória de vida e todas as formas de fuga diante da sua identidade negra, tais como: a negação da religião, a rejeição à Ifigênia, os modos de vestir-se e comportar-se, a negação do samba e de sua origem na favela, etc. Emanuel e Ifigênia, por meio do rito de passagem simbolizado pela obra, por fim, reconciliam-se com suas identidades negras. Emanuel aceita o sacrifício a ele impingido pela espada de Ogun, enquanto Ifigênia veste a coroa de Ogun, empunha sua espada e transforma-se na heroína da comunidade. Deste modo, um e outro se reencontram com sua ancestralidade.

\section{A tríade - Exu/Pombagira/Ogum}

No que tange à dimensão religiosa, nesta versão, surge mais visivelmente a figura de Ogun compreendida em termos das personagens na tríade Exu/Pombagira/Ogun, que vai marcar o final da trama, realizando o sacrifício de Emanuel ao final.

Uma das principais diferenças entre as versões, em Sortilégio II, a rubrica de apresentação da personagem Ifigênia dá o primeiro indício de transformação do desfecho dado à personagem,e dá margem a outra interpretação com relação à sua função social, que fica atrelada definitivamente a prostituição, pela presença da palavra “agora”, que indica uma temporalidade situada, o que não fixa a personagem em um destino imutável, aferrado ao estereótipo de prostituta. Isso indica uma possibilidade de transformação de sua condição e não um encerramento num tipo de essencialidade. Além disso, sua condição social e profissão não estão mais atreladas somente à cor da pele, como figurava na primeira versão. Consta da apresentação das personagens:

IFIGÊNIA - “Ex-namorada de Emanuel, agora uma prostituta” (NASCIMENTO, 1979, p. 38).

Ainda da primeira para a segunda versão, outra mudança fundamental no texto reside na aparição inaugural de Ifigênia em relação à entidade que se saúda. Na rubrica da primeira versão, consta: 
(Acende o defumador. Envolta na fumaça e no meio do tronco que se ilumina fracamente, aparece Ifigênia com um foco de luz esverdeada no rosto. Uma negra jovem, vestida espalhafatosamente de mau gosto. Fuma constantemente. Tanto quanto possível, gesticula e se movimenta mecanicamente, como boneco. Sempre que entra, ouve-se o "ponto" de Inhansã, pelo coro invisível dos filhos e filhas de santo. Saúdam: “Êpa Rei. Êpa Rei”) (NASCIMENTO, 1961, p. 170).

Já na segunda versão, a figura da Pombagira tem outra roupagem, com sutis e significantes diferenças de valor:

(Acende o defumador. Envolta na fumaça e no meio do tronco da gameleira que se ilumina fracamente, sai Ifigênia sob um foco de luz esverdeada. Negra jovem, traje vistoso, brilhante, mas de gosto duvidoso. Fuma constantemente, nervosamente. Movimentos e gestos que lembram marionetes. Sempre que a aparece em cena, ouve-se o ponto de OyáInhansan ou de Pombagira. Saúdam. “Eparei”.) (NASCIMENTO, 1979, p. 69-70, Grifo nosso).

Acrescenta-se, portanto, a possibilidade de que um ponto de Pombagira seja cantado em suas aparições, o que parece ser uma valorização desta entidade que, por não ser considerada um Orixá (assim como, por sua aproximação com mundos mais obscuros, tal e qual Exu) costuma ter sua imagem desvalorizada. Em diversos momentos da obra, é possível encontrar características atribuídas a Exu/Pombagira, também reconhecíveis nas atitudes de Ifigênia. Assim, desenha-se um paralelo entre as duas entidades, que se complementam; o que fica evidente na demarcação de Juliana Santos (2002) do ponto de intersecção entre os dois:

[...] é o portador mítico do sêmen e do útero ancestral e como princípio de vida individualizada ele sintetiza os dois. É por isso que, frequentemente, ele é representado sob a forma de um par, uma figura masculina e uma figura feminina unidos por fileiras de cauris (SANTOS, J., 2002, p. 163).

Conforme pontua Nascimento (2003), a obra acontece nos planos social, psicológico e mítico-religioso, pois que Exu confunde o tempo, fazendo com que passado, presente e futuro se misturem; de tal forma que Emanuel, em fuga e atordoado, não sabe que horas são e, tampouco, onde está. Somente quando se ouve as doze badaladas, é que ele se dá conta da hora. Concluindo que esta é a hora em que Exu aparece, percebe que chegou ao terreiro e pressente o perigo.

Quanto à Pombagira, destacamos abaixo diversos trechos da obra onde observamos algumas características atribuídas à entidade:

EMANUEL - surpreso - Você aqui?! O que é que você quer? Ainda me perseguindo? (crescente superioridade e desprezo em sua fala) Pode rir, negra ordinária. Foi o que sempre fez: rir-se de mim... (NASCIMENTO, 1979, p. 70).

$[\ldots]$

EMANUEL - com raiva - Lembra-se, Ifigênia? (ela balança a cabeça sorrindo) E nenhuma desgraça cai sobre sua cabeça? [...]

IFIGÊNIA - dependura-se no pescoço dele, amorosa; é a antiga namorada - Eu queria ser muito amada... Gosta muito de mim? Gosta mesmo? Fala! Gosta de verdade? [...]

IFIGÊNIA - abraça-o e beija-o na boca - Planejei que fosse assim de surpresa, nosso primeiro beijo. (rindo) Gostou? O que é que está sentindo? 
EMANUEL - emocionado - Se você soubesse! Se eu pudesse dizer... Tanta coisa!... Sinto... um turbilhão por dentro...Difícil explicar sentimento tão intenso... Acho que... primeiro... uma sensação de paz... de plenitude... Depois... vê aquela lua grávida... subindo lentamente? É... como se eu estivesse montado nela... (sorri) Um São Jorge... espiando o mundo lá do alto... Nada cá de baixo me atingindo mais... nem a prisão... ou a complicação deste mundo duro... A palavra exata é esta: transfiguração. Transfigurei-me num ser alado... Meus pés não tocam a face da terra... Viajo para o infinito... para o eterno... Livre... livre... IFIGÊNIA - voltando a ser a prostituta vulgar - Safa! Nunca imaginei que um simples beijo fosse capaz dessa calamidade... Provocar tanto palavrório... Tanta literatura barata! (NASCIMENTO, 1979, p. 96-97).

Segundo Silva (2015), a Pombagira seria um trickster feminino que desafia a ordem patriarcal da sociedade pela sua insubordinação aos papéis sociais. É a mulher da rua e, ainda que seja vista também como mãe, leva a marca da prostituta. Com tudo isso, questiona estes lugares destinados pelo sexo biológico de modo jocoso e aponta que é do domínio sobre seu corpo que vem o seu poder - essa liberdade que a confina ao estigma de mulher “desclassificada”. O estatuto marginal, mais uma vez, a aproxima de Exu. Ainda sobre a condição corpórea híbrida e em trânsito destas duas entidades, comenta Silva (2015, p. 81-2):

\begin{abstract}
Passaram a despertar na sua condição simultânea de marginais sociais [...] e de reconhecidos agentes da transformação do mundo por meio de um suposto e privilegiado manuseio de "ferramentas mágicas". Imagens de seres "mistos" fornecem, portanto, uma boa metáfora de uma sociedade que se vê como resultante do trânsito transatlântico de corpos e culturas que modelaram um mundo unido e dividido, único e múltiplo. É, pois, a capacidade de interagir ou dividir, de provocar o consenso ou o dissenso, de juntar os opostos ou separar os pares, de obedecer ou subverter as regras, que Exu, em suas inúmeras faces, exprime o seu poder no Brasil.
\end{abstract}

As armas das entidades e Orixás, tanto no candomblé quanto na umbanda, são sínteses das forças que evocam. Na mitologia assim como no culto, cada arma anuncia a presença desta ou daquela força, além de anunciarem a ligação da pessoa com o orixá em si. Na primeira versão, a lança que sacrifica Emanuel é a de Exu; já na segunda, é a espada de Ogun. É a fala de uma das Filhas de Santo e a voz de Exu que anunciam essa mudança significativa:

VOZ DE EXU - disforme, irreal - Que quero aquele filho da puta aqui, de rastros, antes da hora grande. (NASCIMENTO, 1979, p. 52).

$[\ldots]$

FILHA III - feliz - Ninguém tocará nele. Só a espada de Ogun! (NASCIMENTO, 1979, p. 55).

Ainda segundo Juliana Santos (2002), esta relação entre Exu e Ogun se conforma da seguinte maneira:

Èsù Elegbára é o companheiro inseparável de Ògún, a ponto de chegarem a confundir-se. No "terreiro", rituais especiais devem ser celebrados durante a iniciação do Ològùn sacerdotes de Ògùn - para evitar que Èsù se manifeste neles, o que ultrapassaria suas forças. Com efeito, nos “terreiros” tradicionais, Èsù não se deve manifestar. Princípio 
dinâmico e símbolo complexo que participa de tudo que existe, sua força abstrata acompanha e só pode ser representada "por meio de" Ògùn que o representa (SANTOS, J., 2002, p. 134).

Na segunda versão, parece ser a partir desta nova manifestação das forças das divindades que se estabelece a reviravolta também na qualidade da personagem Ifigênia. A relação intrínseca entre Exu e Ogun realiza a intersecção entre as duas entidades e Ifigênia, já que ela (tendo como companheira constante a Pombagira) é um Exu feminino.

Pode-se entender, por fim, uma relação entre as três entidades e sua harmonização e articulação, necessária para que Emanuel e Ifigênia sigam o caminho do terreiro para que ali, cada um de sua maneira se reconcilie com o Ayé (mundo dos vivos) e com o Orum (mundo dos mortos).

As entidades de Exu, Pombagira e Ogun realizam essa relação com o infinito, juntamente com as Filhas de Santo e a Yalorixá ${ }^{10}$.

[...] Ogum está associado ao reino mineral, mais precisamente ao ferro, portanto, suas representações materiais são as diferentes ferramentas utilizadas na agricultura e na arte bélica. Em função disso, todas as conquistas técnicas lhe são conferidas, sendo ele considerado também vanguarda da civilização - o primeiro, o primogênito. (CARNEIRO e CURY, In: Nascimento, 2008, p. 103).

Assim, essas personagens, interagindo com o mundo dos humanos e influenciando em seus atos, conduzem o espaço ritualístico da obra, sendo ao mesmo tempo duplos dos humanos ali representados e das produções culturais dos viventes.

\section{Ialorixas e Filhas de Santo}

Destacamos a seguir os pontos de vista e as movimentações das mulheres negras nas duas obras, observando as mudanças ocorridas no destino da protagonista negra feminina, Ifigênia, ao lado de outras diferenças fundamentais na segunda versão que dizem respeito às outras personagens femininas da trama.

10 No Brasil, a principal sacerdotisa de uma casa e santo (terreiro de candomblé) é a ialorixá, a quem cabe a distribuição de todas as funções do culto praticado nas comunidades-terreiro de orixá e a mediação entre os homens e os orixás. Seu equivalente masculino é o babalorixá. São conhecidos também como pai de santo e mãe de santo. A ialorixá e as demais autoridades do terreiro funcionam como no governo das tribos africanas, que tem um líder supremo (ialorixá ou babalorixá), chefes conselheiros do rei (mães pequenas, ogãs, ekédis) e subchefes setoriais (responsáveis pela cozinha, pelas folhas, pelos sacrifícios, pela administração do terreiro, etc.). (THEODORO, 2013, p. 50). 
Iniciaremos pelo surgimento da personagem Ialorixá, responsável pela preservação do axé ${ }^{11}$ do terreiro. Dentre as diversas funções de uma Ialorixá, destaca-se seu poder na resolução de problemas a partir do seu conhecimento dos mistérios do culto e das forças da natureza. Ainda que o autor deixe em aberto a possibilidade de que possa ser um Babalorixá, a escrita utiliza uma Ialorixá. Essa opção reconhece a importância das mulheres negras na manutenção e guarda dos costumes religiosos vindos da África, pois foram elas que impediram que essas práticas se perdessem, fosse “negociando" com o cristianismo, por meio do sincretismo religioso (no caso de diversas Mães de Santo que se afirmavam católicas), fosse construindo diálogos com os governantes para a permanência de seus terreiros (assim, impedindo seu fechamento, com a apreensão de objetos religiosos pela polícia) (CARNEIRO, 2011).

As Filhas de Santo são uma personagem coral que serve de apoio à Iálorixá (a mãe de santo), replicando a relação entre coreuta e coro da tragédia grega. A dupla Ialorixá e as Três Filhas de Santo também fazem alusão à hierarquia de uma casa de candomblé, em que a autoridade da sacerdotisa, escolhida por seus conhecimentos para assumir o cargo, não prescinde da assistência de todos. Logo na primeira cena da segunda versão estão a Ialorixá e as três Filhas de Santo, anunciando essa parceria. Enquanto a primeira joga o Opelê - jogo adivinhatório -, as Filhas perguntam sobre o que diz o jogo. Ela lhes fala sobre os orixás e sobre Exu e lembra que está na hora da comida dele. Assim, as filhas começam a feitura do despacho, que é acompanhado por ela; rito que se desenvolve em forma de cena, diferentemente da primeira versão, em que é apenas comentado pelas Filhas de Santo. Quando terminam o despacho, o texto repete o da primeira versão:

I FILHA DE SANTO - Pronto: Obrigação cumprida! (NASCIMENTO, 1979, p. 49).

Verificamos, então, neste momento a importância dada as personagens femininas no ritual, na qual consta para além da fala, as suas presenças e ações, demonstrando o valor da obrigação que está sendo cumprida, enquanto a Ialorixá lhes conta as histórias das divindades, e deste modo, apresenta a forma de transmissão de conhecimento africano, a tradição oral, que mantêm as das

11 O àse é contido numa grande variedade de elementos representativos do reino animal, vegetal e mineral quer sejam da água (doce ou salgada) quer da terra, da floresta, do “mato” ou do espaço "urbano”. O àse é contido nas substâncias essenciais de cada um dos seres, animados ou não, simples ou complexos, que compõem o mundo. (SANTOS, J., 2002, p. 41). 
histórias dos mitos que passam de geração a geração pela força da palavra.

Também na cena onde se rememora o casamento de Emanuel e Margarida, tendo sido alongada, tem-se uma maior participação das Filhas de Santo, com intervenções textuais inseridas, como na fala ao final do trecho:

FILHA III - Exato. Igual à borboleta que abandona o casulo pra poder voar... Emanuel deixará a casca do ser que não é o seu próprio ser. Mas... devemos esperar os acontecimentos. Por enquanto ele é apenas uma fração de ser inquieta... incapaz de parar e repousar [...] (NASCIMENTO, 1979, p. 66).

Aqui, o papel mais destacado das Filhas de Santo pode ser atribuído a sua capacidade de oferecer poeticamente um arrazoado do ocorrido e de anunciar novos eventos: elas, desse modo, demonstram a habilidade de atravessar os feitos ordinários e de enxergar mais adiante. Quando se aproxima o momento de Emanuel cumprir o sacrifício, também é a fala da Ialorixá que antevê o seu destino:

IALORIXÁ - Disse antes e repito: Emanuel compreendeu por si mesmo. Exu apenas ajudou. Mas foi no amadurecimento que ele se uniu e se tornou um só com Ogun. Os dois deram um nó aos fios desunidos [...] foi isto que aconteceu. Emanuel deixará de ser [...] (NASCIMENTO, 1979, p. 125).

Estes são mais um reconhecimento do papel das mulheres negras e da importância da sua presença dentro dos terreiros e da vida social. A importância da personagem da Ialorixá é mais uma vez destacada quando é ela quem conduz a transformação simbólica do palco em Quilombo do Palmares, numa evocação ao mesmo tempo épica e mágica:

IALORIXÁ - Que as nuvens desatem sua tempestade! Que o vento furioso sopre! Que rasgue o espaço o relâmpago fulminante! Xangô redivivo em Zumbi![...]

- Palmas verdes renascem ao sopro curador de Ossain... Treme, quilombo ao ronco de Xangô![...]

- Africanos alevantados[...]

- Quilombolas imortais, de pé![...]

- Liberdade do povo negro[...]

- Dignidade da raça

- Poder da nação

- Axé, Ogun! Okegun!

- Axé, Zumbi! Okezumbi! (NASCIMENTO, 1979, p. 136-138).

Tanto as Filhas de Santo quanto a Ialorixá têm papel preponderante no desenrolar do ritual atualizado na peça. Elas, assim como Ifigênia - a mulher negra preterida - têm a incumbência de evidenciar momentos da vida do herói, em que este sofre diversas violências, mostrando a razão de sua recusa da identidade negra. Suas ações, entretanto, atravessam o tempo mítico para mudar o contexto real, que se desenrola no tempo histórico da peça (na moldura da ficção) para, em espelhamento, agir sobre o tempo histórico propriamente dito (numa espécie de intervenção no "real do real”). 
Esta versão, assim como a primeira, efetua deslizamentos constantes entre o estatuto ficcional e o contexto nacional, no que diz respeito à realidade das relações inter-raciais e à situação social de homens e mulheres afrodescendentes. Tanto Emanuel quanto Ifigênia sofrem as consequências de uma estrutura que não lhes permite mobilidade social e, tampouco, oportunidades de uma vida plena em termos afetivos. Frente a esse impasse, a obra vislumbra um caminho de transformação pela transcendência e pela prática cotidiana da religião, espaço que é ordenado e conduzido pela Ialorixá e as Três Filhas de Santo.

O reconhecimento da potência social da religiosidade, entretanto, não nega a realidade material e os dramas da vida real dos negros e negras. Assim, no coro representado pelas Filhas de Santo, as falas remetem à condição de objeto das mulheres negras desde o período da escravidão, como se essa marca ainda se fizesse presente. Ao mesmo tempo, outros momentos do coro apontam a mudança nesse destino (falas que não existem na primeira versão), como resume a Filha III:

FILHA III: Mas agora vamos mudar, transformar tudo (NASCIMENTO, 1979, p. 75).

Deste modo, fica evidente que cabe às personagens femininas (principalmente, à Ialorixá) serem exemplos, arautos e viabilizadoras de uma nova condição para homens e mulheres negros, o que faz jus à posição das religiões afro-brasileiras na cultura negra:

Dessa forma, o candomblé parece oferecer à mulher novos modelos de comportamento que se contrapõem aos papéis institucionalizados pela ideologia dominante. A maioria, das iyalorixás que conhecemos em São Paulo é de mulheres que vivem e sobrevivem sozinhas, e as que têm maridos ou companheiros fixos não se mostram submissas ou submetidas à figura masculina (CARNEIRO e CURY: In: NASCIMENTO, 2008, p. 140).

Conforme exemplifica Sortilégio II, na visão de Abdias do Nascimento este não é um projeto utópico, mas algo a ser efetivado agora. Em seguida do sacrifício de Emanuel, as mulheres comemoram o cumprimento da missão a que foram incumbidas, na fala de encerramento - fala que é repetida nas duas versões:

FILHAS I, II e III (juntas, devagar) - Pronto: obrigação cumprida! (NASCIMENTO, 1979, p. 139).

\section{Matriarcado da Miséria}

A relação entre as duas obras permite traçar a trajetória completa da personagem Ifigênia. Voltemos à trama. Mulher negra, Ifigênia, depois de ter sido abusada por um homem branco, é preterida por Emanuel, homem negro e grande amor de sua vida, que escolhe casar-se com uma mulher branca, Margarida. Após ter seu sonho de ser artista destruído, ela encontra como único 
caminho possível a prostituição. Por meio de um ritual religioso, no qual Exu é guia, Ifigênia (ora ela mesma, ora na figura mítica da Pombagira) acompanha Emanuel, agora em fuga pelo assassinato da esposa branca. Ele caminha para o seu sacrifício, situação em que ela também se reconcilia com sua negritude, interrompendo o processo de recusa de si mesmo em que ambos viviam. Ao final deste ritual, Ifigênia toma posse da coroa e da lança de Ogun e se torna a pessoa responsável pela comunidade

Conforme já comentado anteriormente, Ifigênia merece na segunda versão uma função diferente da primeira, realizando o caminho de sacrifício a que Emanuel submete-se voluntariamente. Ifigênia é agente da transformação não só de Emanuel, mas dela mesma e da sociedade, destinada a liderar a comunidade, na figura de Ogun, o orixá guerreiro. A respeito desse desfecho, Custódio (2011, p. 126) comenta:

Agora, na redenção via cultura negro africana, Ifigênia recebe a coroa e a lança de Ogun, sendo também redimida pelos orixás. Agora, em 1979, Nascimento salva as duas figuras negras da peça em uma redenção mais do que artística, ela é localizada e ideológica.

Ao que Nascimento (2003) concorda, ao descrever o final destinado à Ifigênia na segunda versão:

A realização do destino simbólico do herói junta-se com o da heroína e reintegra-se à matriz primordial, comuna, do drama ritual, emergindo livre da convenção ocidental da solidão do indivíduo ante o seu destino. O conteúdo enunciado nessa segunda versão da peça amplia radicalmente o seu alcance e explicita o seu simbolismo. É a abordagem da questão de gênero, fulcro da questão racial, que opera essa mudança. A mulher afrodescendente passa a agir não apenas como agente da salvação do herói, mas como protagonista e líder na emancipação da coletividade beneficiada por esse sacrifício e pelo próprio drama ritual (NASCIMENTO, 2003, p. 346).

Ifigênia encaminha-se em Sortilégio II a uma elevação de estatuto, nos campos do mistério e da arte, anunciando, por meio dos ecos desses campos, uma força poderosa, apta a alterar as determinações opressivas em torno das demarcações de raça-etnia e de gênero ativas na vida ordinária. A transição entre as dimensões da pessoa e da divindade está marcada no contraste entre os trechos abaixo, desde quando ela aparece atrás de Emanuel empunhando a lança de Ogun e sua coroa, para efetivar a passagem do herói, até seu grito final:

(Ifigênia vem desde dentro do pegi; traz o buquê de lírios sangrentos. Ponto de OyáInhansan. Emanuel cai de joelhos, abraça suas pernas. Fala aflito, apressado)

[...]

IFIGÊNIA (forçando um tom cínico para esconder sua perturbação comovida)

- Obrigada. Falou bonito... falou muito. Falou demais. Agora cale-se. Não há mais tempo... o tempo não volta atrás... É absurdo lembrar o que passou. Já consumimos todas as nossas esperanças...[...]

EMANUEL -... Me ajude, Ifigênia! Me ajude! (observa o rosto dela, vê o buquê de lírios) Como é gentil... lírios para mim? Você é um anjo sabe? (beija-lhe a boca, ela permanece fria, então ele se afasta desconfiado) Ma... este lírio... parece o lírio de meu casa... Onde 
arranjou esse buquê? Responda, Ifigênia, o que quer dizer com esses lírios na mão? É esquisito... muito esquisito... me faz lembrar... outra vez...Mas não pode ser, não pode. Porque senão você estaria aqui para... para... É verdade, Ifigênia?

(Ifigênia está chorando silenciosamente; Emanuel sacode-a pelos ombros, ela reage, solta uma gargalhada estridente e sarcástica, a fim de ocultar sua emoção) (NASCIMENTO, 1979, p. 117-119).

$[\ldots]$

(O ponto de Ogun sobe forte; Emanuel abre os braços como se fosse levantar voo, o Orixá desce rápido a espada que atravessa seu pescoço. O herói cai amparado pelas Filhas; Emanuel jaz sobre o altar de Ogun, enquanto o Orixá desaparece rápido. As Filhas de Santo descem ao mesmo lugar do despacho inicial. Ifigênia aparece e fica atrás de Emanuel; ela veste um traje ritual de Ogun).

(Ifigênia põe a coroa de Ogun na cabeça, e empunha lança. O coro, as Filhas e a Yalorixá saúdam Ogunnhiê! E se atiram de comprido ao chão, batendo a cabeça no solo em sinal de reverência e obediência. Seguem-se momentos de silêncio absoluto. Depois Ifigênia levanta a espada num gesto enfático de comando gritando forte Ogunhiê! O ponto de Ogun se eleva e se transforma num ritmo triunfal e heroico) (NASCIMENTO, 1979, p. 139-140 grifos do autor).

Este final heroico de Ifigênia proclama uma nova condição e postura das mulheres negras: a religião opera como forma de resistência para si e para os seus, na manutenção das suas culturas e fé; politicamente, ela mobiliza uma arma de sobrevivência e combate diante de uma sociedade racista, que marginaliza e a subestima as mulheres. A obra ensina essa reversão de expectativas que se dá por meio da insubordinação simbólica, comentada no texto abaixo:

Por meio de sua fé e seu axé, essas mulheres conseguiram trazer até nossos dias imagens sacralizadas do passado, que se volta para a mitologia africana e aponta insistentemente, por meio da tradição oral, as estratégias mais diversas de insubordinação simbólica que lhes possibilitam criar mecanismos de defesa para a sobrevivência e a manutenção de seus traços culturais de origem. A mulher negra se estrutura como uma pessoa que toma para si a responsabilidade de manter a unidade familiar e a coesão grupal e de preservar as tradições culturais e religiosas de seu grupo, em função da nova realidade que a opressão econômica e a discriminação racial pós-abolição criaram no seio da sociedade brasileira (THEODORO, 2006, p. 92).

Os qualitativos da feminilidade que eram presentes em Ifigênia, passíveis de crítica por reproduzirem as expectativas de gênero de uma sociedade sexista e classista, são transcendidos pela junção entre os atributos femininos e masculinos, que as entidades do candomblé aportam. Sobre a transmutação de “identidade de gênero" de Ifigênia quando passa a representar Ogun, Carneiro e Cury, In: Nascimento (2008, p. 131-132) resumem:

[...] embora seja mulher, filha de orixá feminino e lute com dificuldade para sobreviver e criar seus filhos, diante de situações extremadas transmuta-se em Ogum, a representação máxima da virilidade, combatividade e masculinidade no candomblé. [...] Dessa forma, escudadas nas qualidades dos orixás femininos, as mulheres dão nova dimensão aos atributos femininos; escudadas nos orixás masculinos e nos caboclos, elas competem com o homem em seu próprio terreno e se equiparam à virilidade masculina. Em qualquer dos casos, o candomblé abre um campo de vivência de papéis que tradicionalmente são negados a elas.

Em correspondência ao que o autor demonstra com este final (a maior valorização das 
mulheres negras a partir da religião), vê-se na experiência das mulheres nas comunidades de candomblé a importante atuação das lideranças femininas para a manutenção da tradição que nos chega até hoje:

A mulher das comunidades-terreiro, do povo de axé, caracteriza-se por um passado de luta, determinação e resistência, e simboliza aquela que podemos identificar como a "mulher de candomblé". Ela enfrenta adversidades e problemas de qualquer ordem, possibilitando uma autoimagem e uma autodefinição como mulher sem papas na língua, de raça, que não tem medo de nada (THEODORO, 2008, p. 92-3)

O que está em jogo, portanto, é a possibilidade de construção de uma autoimagem mais autônoma e livre, no sentido de um destemor, garantido pela afirmação de uma identidade cultural negra, por um lado, e pelo axé, por outro. Em entrevista à Wernek, Mendonça e White (2006), Mãe Beata de Yemonjá12 ${ }^{12}$ relata parte de sua trajetória como Ialorixá, na qual visualizamos o quanto suas atividades não se restringem ao espaço do terreiro e ao candomblé, estendendo a atuação da Ialorixá para a comunidade à qual pertence e para além de suas fronteiras geográficas. Ela relata:

\begin{abstract}
Quando poderia imaginar que um dia iria viajar e dar palestras sobre Candomblé na Alemanha, em Nova York e na Universidade de Stanford? Hoje faço parte do maior fórum espiritual do mundo, o Fórum Global das Religiões, onde trabalhamos pela paz. Trabalhei com o Betinho na Campanha contra a fome e hoje faço parte da Viva Rio. Participo do Grupo de Mulheres Negras do Rio de Janeiro e sou filiada ao PT. Aqui na comunidade, organizamos oficinas de teatro e aulas de português, história e computação para 25 adolescentes (MÃE BEATA DE YEMONJÁ apud WERNEK; MENDONÇA; WHITE, 2006, p. 18).
\end{abstract}

Mãe beata assume essas funções e reconhece nessa pluralidade de intervenções o seu espaço de sacerdotisa, liderança e mulher ativista. É de extrema importância para o destino de Ifigênia, na obra, a aquisição dessa consciência, digamos, ativista; sem desmerecer, evidentemente, a luta heroica destas mulheres negras já quando enfrentam as dificuldades e as condições precárias em que, em geral, vivem (além das responsabilidades de criar, sozinhas, seus filhos e sustentar a casa, ainda carregam a obrigação de manter viva a tradição da religião).

Sobre este pesado fardo carregado pelas mulheres negras, enquanto grupo mais frágil em sua posição social, Carneiro (2011) replica o termo cunhado por Arnaldo Xavier - poeta negro nordestino-, o “matriarcado da miséria”:

[...] para mostrar como as mulheres negras brasileiras tiveram sua experiência histórica marcada pela exclusão, pela discriminação e pela rejeição social, e revelar, a despeito dessas condições, o seu papel de resistência e liderança nas comunidades miseráveis em

12 Mãe Beata de Yemonjá nasceu na Bahia. É Ialorixá em Nova Iguaçu, Rio de Janeiro, iniciada pela Ialorixá Olga de Alaketu. Escritora, publicou seu primeiro livro Caroço de Dendê pela Editora Pallas, RJ. É fundadora e coordenadora do Instituto de Desenvolvimento Cultural de Nova Iguaçu, RJ. (WERNEK; MENDONÇA; WHITE, 2006, p. 16). 
todo o país. (CARNEIRO, 2011, p. 130).

Quando aponta sobre as condições das mulheres negras arrimo de família, por meio do “matriarcado da miséria”, Carneiro (2011) discute as contradições do protagonismo de mulheres negras na realidade nacional, reconhecendo que a luta por elas empreendida deixa lacunas em suas vidas. Elas carregam uma marca de resistência, que por vezes, faz com que pareçam destituídas de delicadeza e fragilidade, comumente associadas às mulheres brancas. O mesmo processo (resquício de uma sociedade escravocrata, não superado historicamente) faz com que, nós mulheres negras, carreguemos ainda o estigma da mulher negra raivosa, não sem motivos: com a soma de racismo e sexismo, não poderia ser de outra maneira, até que tenhamos uma sociedade de fato igualitária.

A consciência de luta, assim, acompanha as marcas do "matriarcado da miséria”, sem que sejam concordantes, nem separáveis. É o que comenta hooks (2017, on-line):

\begin{abstract}
Antes que as mulheres pudessem mudar o patriarcado, tivemos que mudar a nós mesmas; tivemos que criar nossa consciência. A conscientização feminista revolucionária enfatizou a importância de aprender sobre o patriarcado como um sistema de dominação, como se institucionalizou e como é perpetuado e mantido. Compreender a forma como a dominação masculina foi expressa na vida cotidiana criou consciência nas mulheres das formas em que fomos vitimizadas, exploradas e, em piores situações, em cenários oprimidos.
\end{abstract}

Este processo de conscientização, que hooks localiza entre os grupos feministas dos anos 1970, tingiu-se da explosão do sentimento de raiva, fruto da hostilidade reprimida. Tal fundo emocional, contudo, foi sendo superado, segundo hooks, pela colaboração e escuta entre as mulheres e, posteriormente, pela eleição de pautas e formas de luta, que transformaram em ações coletivas efetivas o isolamento e o ódio represados. Essas ações estão abrigadas no nome “movimento feminista”, em seus termos, “[...] um movimento para acabar com o sexismo, a exploração sexista e a opressão” (hooks, 2017, on-line).

\title{
Considerações Finais
}

Assim, é esse mesmo impulso de guerra, movido pelos sentidos de justiça e reparação, que Abdias do Nascimento vê e traduz no papel da personagem Ifigênia. Cabe ponderarmos, entretanto, que embora importante, não seria este o único destino permitido às mulheres negras. Mas, levando em conta o período em que a peça foi escrita, ainda com um feminismo negro brasileiro em processo de gestação, pode-se entender na solução do autor uma forma de valorização da capacidade de resistência das mulheres.

É preciso lembrar, ainda, o fato de Sortilégio II ser uma dramaturgia escrita por um homem 
negro, na qual o herói da obra é um homem, personagem melhor construída em sua subjetividade do que as personagens femininas da peça. Além disso, é visível que o modelo de herói adotado pelo autor segue sua própria experiência masculina no mundo e, ao mesmo tempo, os ditames de um modelo teatral também concebido segundo uma lógica sexista, na qual o herói costuma ser um homem, num mundo dominado por homens. Este partido poderia ser diverso, se a experiência criadora fosse nutrida por outro conjunto de visões, ou por meio da emergência de um olhar propenso à experiência sensível, afetiva e intelectual das mulheres negras.

\section{REFERÊNCIAS BIBLIOGRÁFICAS}

ALMEIDA, Elaine. Sortilégio, mistério negro, de Abdias do Nascimento: o Teatro Experimental do Negro e a censura. In: COSTA, Cristina (Org.). Leituras e releituras: Sete peças vetadas pela censura lidas e analisadas na atualidade. São Paulo: Instituto Palavra Aberta, 2017, p.111-131.

ALMEIDA, Silvio. O que é racismo estrutural? São Paulo: Editora Letramento, 2018. (Coleção Feminismos Plurais).

CARNEIRO, Sueli. Racismo, Sexismo e Desigualdade no Brasil. São Paulo: Edições Selo Negro, 2011

CORRÊA, Mariza. Sobre a Invenção da Mulata. Cadernos Pagu, Campinas, n. 6-7, p.35-50, 1996.

CUSTÓDIO, Túlio Augusto Samuel. Construindo o (auto)exílio: Trajetória de Abdias do Nascimento nos Estados Unidos, 1968-1981. 2011. Dissertação (Mestrado em Sociologia) Universidade de São Paulo, Faculdade de Filosofia, Letras e Ciências Humanas, São Paulo, 2011.

DAVIS, Angela. Mulheres, raça e classe. Tradução Heci Regina Candiani. São Paulo: Boitempo, 2016.

GONZALES, Lélia. Racismo e Sexismo na Cultura Brasileira. Revista Ciências Sociais Hoje ANPOCS. São Paulo, p. 223-244, 1984.

GILROY, Paul. O Atlântico Negro. Rio de Janeiro: Editora 34, 2012.

hooks, bell. Feminismo é para todos. In: Criação da Consciência - uma constante mudança de coração. (2017Tradução Carol Correia. [on-line]. (Capítulo 2). Disponível em: https://medium.com/qg-feminista/capítulo-2-de-feminismo-é-para-todos-por-bell-hooks45719cb19ca6. Acesso em: 18 abr. 2019.

MARTINS, Leda Maria. A cena em sombras. São Paulo: Editora Perspectiva, 1995.

NASCIMENTO, Abdias. Dramas para Negros e Prólogo para Brancos - Antologia de Teatro Negro Brasileiro. Rio de Janeiro: Edição do Teatro Experimental do Negro, 1961. 
. O quilombismo - Documentos de uma militância pan-africanista. Petrópolis: Editora Vozes, 1980. 1979.

. Sortilégio II - Mistério Negro de Zumbi Redivivo. Rio de Janeiro: Editora Paz e Terra,

NASCIMENTO, Elisa Larkin. Sortilégio da Cor: Identidade, raça e gênero no Brasil. Selo Negro Edições: São Paulo, 2003.

. Guerreiras da Natureza: Mulher negra, religiosodade e ambiente. Selo Negro Edições: São Paulo, 2008.

Orí. Direção: GERBER, Raquel. Produção: Pedreira, Álvaro; Ganimedes, Beth; Santiago, Daniel; Fontes, Flávia; Elias, Paulo Souza; Chamlian, Regina; Azevedo, Robson. Roteiro: Maria Beatriz Nascimento. Elenco: Maria Beatriz Nascimento. Música: Naná Vasconcelos, Mathias Gohl. Edição: Renato Neiva Moreira. São Paulo: Angra Filmes Ltda.; Fundação do Cinema Brasileiro. Distribuidora: Angra Filmes, 1989. (91min).

RATTS, Alex. Eu sou atlântica: Sobre a trajetória de vida de Beatriz Nascimento. São Paulo: Imprensa Oficial do Estado de São Paulo, 2006.

; RIOS, Flávia. Lélia Gonzalez. São Paulo: Selo Negro Edições, 2010.

RIBEIRO, Djamila. O que é lugar de fala? São Paulo: Editora Letramento, 2017. (Coleção Feminismos Plurais).

. Quem tem medo do feminismo negro? São Paulo: Companhia das Letras, 2018.

RIVAS, Maria Elise G. B. M. Nem Maria, nem Eva, apenas Pombagira! In: RIVAS NETO, Francisco (Org.). Exu e Pombagira uma visão teológica. São Paulo: Arché Editora, 2015. p. 7790.

SANTOS, Juliana Elbein. Os Nagô e a Morte - Pàde, Ásèsè e o Culto Égun na Bahia - 11ª Edição. Petrópolis: Editora Vozes, 2002.

SILVA, Vagner Gonçalves. Exu: O guardião da casa do futuro. Rio de Janeiro. Editora Palas, 2015.

SOUZA, Claudete Alves da Silva. A solidão da mulher negra - sua subjetividade e seu preterimento pelo homem negro na cidade de São Paulo. 2008. Dissertação (Mestrado em Ciências Sociais) - Pontifícia Universidade Católica de São Paulo, São Paulo, 2008.

SOUZA, Neusa Santos. Tornar-se Negro ou As Vicissitudes da Identidade do Negro Brasileiro em Ascensão Social. Rio de Janeiro: Graal:, 1993.

SODRÉ, Muniz. Sobre a identidade brasileira. Revista Científica de Información y Comunicación, Rio de Janeiro. n. 7, p. 321-330, 2010.

THEDORO, Helena. Iansã - Rainha dos Ventos e das Tempestades. Rio de Janeiro: Editora Pallas, 2013.

WERNEK, Jurema; MENDONÇA, Maisa; WHITE, Evelyn C. (Orgs). O Livro da Saúde das 
Sankofa. Revista de História da África e de Estudos da Diáspora Africana Ano XIII, NºXXIII, abril/2020

Mulheres Negras - Nossos Passos Vêm de Longe. Rio de Janeiro: Pallas e Criola, 2006. 